$50 \mid 2019$

Animals in the religion and culture of the Tibetan

Plateau

\title{
A multifaceted interdependence. Tibetan pastoralists and their animals
}

Une interdépendance à facettes multiples. Pasteurs-nomades tibétains et leurs animaux

Nancy E. Levine

(2) OpenEdition

Journals

Electronic version

URL: https://journals.openedition.org/emscat/3822

DOI: 10.4000/emscat.3822

ISSN: 2101-0013

\section{Publisher}

Centre d'Etudes Mongoles \& Sibériennes / École Pratique des Hautes Études

\section{Electronic reference}

Nancy E. Levine, "A multifaceted interdependence. Tibetan pastoralists and their animals", Études mongoles et sibériennes, centrasiatiques et tibétaines [Online], 50 | 2019, Online since 04 March 2019 connection on 13 July 2021. URL: http://journals.openedition.org/emscat/3822 ; DOI: https://doi.org/ 10.4000/emscat.3822

This text was automatically generated on 13 July 2021 .

(c) Tous droits réservés 


\title{
A multifaceted interdependence. Tibetan pastoralists and their animals
}

\author{
Une interdépendance à facettes multiples. Pasteurs-nomades tibétains et leurs \\ animaux
}

Nancy E. Levine

The research on which this paper is based was supported by grants from the Committee on Scholarly Communication with China (1994), The University of California, Los Angeles's International Studies and Overseas Programs (1994), and the National Science Foundation's U.S.China Cooperative Research Program (1997). Thanks are due to Lopsang Gelek and Dawa Tshering, who worked with me in these various projects, to Clark Barrett for help with statistical analysis, to Kelly A. Hopping and Yonten Nyima for discussions of herd reduction policies in the T. A. R., to Mia Bennett with assistance in mapmaking, and to Lama Chönam and Sangye Khandro for assistance in translation. The section of this paper on snow disasters was presented at the panel Tibetan Social Change at the $16^{\text {th }}$ World Congress of the International Union of Anthropological and Ethnological Sciences, Kunming, China (July 2009).

1 The lives of eastern Tibetan pastoralists, known as drogpa ('brog $\left.p a^{1}\right)$, were traditionally tied to a particular place and a particular kind of livelihood: the high altitude grasslands across which they moved with the seasons and the management of domestic animals. Their relationships with those animals - yaks, crossbred cattle, sheep, goats, and horses, as well as the dogs that guarded the herds - can be described as a multifaceted interdependence. Pastoralists viewed their animals through many different lenses, as conditioned by their economic value, personal bonds, and other relationships binding them. They organized their lives around caring for their animals, while depending on them for their survival. Their animals' milk and flesh, wool, hair, skins, and dung provided their food, clothing, and housing and fuelled their hearths. Pastoralists also relied on riding and pack animals for transport. Having a substantial and healthy herd offered, at once, a sense of security, confirmation of a household's good luck, and validation of its members' skills at managing animals. The animals, 
moreover, served as the storehouse of the household's material wealth and guarantors of its members' fates and fortunes. Particular animals served as intermediaries in human social relationships; they also linked the worlds of humans and local deities and inflected karmic fates.

2 This paper focuses on the period of the late $20^{\text {th }}$ century, in advance of the rapid socioeconomic changes prompted by Chinese government policies, and on three dimensions of the complex multi-species encounter at that time. It begins with the pragmatic side of animal management and provides indirect evidence that these pastoralists used a rough calculus to balance their household's needs and work capacities against their animals' needs for care in order to achieve a productive, economic symbiosis. The paper then turns to the challenges created by the severe weather events that claimed many animals' lives in the 1980s and 1990s and the strategies pastoralists used to rebuild their herds after these disasters ${ }^{2}$. Finally, the paper discusses how pastoralists set aside certain animals as exempt from sale and slaughter and the combination of culture, emotional attachments, and Buddhist-influenced religious ideas that contributed to this practice. Ultimately, the paper will argue that pastoralists' relations with their herd animals displayed a complex, multifaceted mix of pragmatic-economic and cultural-religious logics.

3 First, however, I will describe the recent history and introduce the places on which I have drawn for this portrayal of cultural ideas, values, and practices relating to herd animals. These ideas involve overlapping notions that can be described as culturalreligious and pragmatic-economic and are further influenced by affective bonds with particular animals.

\section{A changing ethnographic landscape}

4 The late $20^{\text {th }}$ century was a transitional era for eastern Tibetan pastoralists. It was more than a decade after the government had instituted the household responsibility system (khyim tshang 'gag tshan len; Ch. jiātíng liánchăn chéngbāo zérènzhi), which ended the collective system of production that had begun in the 1960s and ushered in a return to certain features of traditional pastoralist lifeways. What we know about life in traditional times is limited, confined to glimpses offered by missionaries and travellers and the ethno-historical scholarship of the mid-20 $0^{\text {th }}$ century (most notably, Ekvall 1968, Lobsang Gelek 2002a, 2002b, Rinzin Thargyal 2007). Seemingly paradoxically, we know even less about social life during the collective period. We know more about the radical changes made to the pastoralist economy, notably the institution of production teams, which replaced individual households in managing livestock, allocating labour, and distributing resources, as well as the requirement to deliver specified numbers of animals and pastoral products to government offices. And while much has been written about the destruction of religious institutions and the banning of private religious practice, we know virtually nothing about how the massive political and economic changes engineered during this period affected domestic life.

5 When the collectives dissolved, people took their shares of their production teams' animals and joined them to the small numbers of milk and riding animals that they had cared for on their own. Households again became the primary units of production and consumption and returned to managing the seasonal cycle of movement with their own local groups ( $r u$ skor encampments and the larger tsho $b a^{3}$ ). During this time, 
pastoralists endeavoured to reconstruct many features of their former mobile lifestyle, patterns of social relationships, and ceremonial life, as well as to rebuild religious institutions. These were the circumstances of the period observed and described in this paper.

Massive changes to these local economies, however, were underway. In prior years, the government had mapped regional boundaries and assessed the capacity of regional grasslands. These assessments were used to create bounded plots of grazing land that were contracted out to individual households (Bauer \& Yonten Nyima 2010). While the introduction of this policy varied in different regions, eastern Tibetan pastoralists received their long-term leases at varying years during the 1990s (Horlemann 2002, p. 254-255, Wu et al. 2012, p. 295, Yan et al. 2005, p. 35). Also in process were new programs meant to support more intensive use of grazing land, involving the construction of durable houses at winter camp sites, fenced-in plots where fodder crops for hay were to be grown, and animal shelters to increase survival rates in harsh winters ${ }^{4}$.

Yet to come were programs that were to have even more dramatic impacts: the creation of new housing tracts in county towns and subsidiary townships for purposes of resettlement. These initiatives were linked to the "Converting Pastures to Grasslands" policy (Ch.tuimu huancao), which was aimed at restricting the use of pasturelands that were deemed degraded or located in ecologically sensitive areas (Bauer \& Yonten Nyima 2010, Yeh 2005, Yundannima 2012). Pastoralists in designated areas have been required to leave their newly contracted lands, some for a limited time and some permanently. In response, many have sold their animals, taken up promises of government support, and moved into the new, resettlement towns. The government has offered financial incentives to still other pastoralists to encourage them to settle down, the most powerful incentive being the promise of a subsidized house ${ }^{5}$. Also contributing to increasing engagements with town economies has been the emergence of a "post-pastoral" economy based on the extraction of medicinal fungi for Chinese and international markets (Breuer \& Gruschke 2016). For many, the most powerful reason for town-based residence is the nation-wide requirement for children's schooling up through the ninth grade.

8 This paper looks back to a period prior to these social and economic changes, to a time and place where the herding economy held sway, in which people defined their identities by their work as pastoralists and experienced their lives through the daily round of care for domestic animals. The focus is on groups living in the upper reaches of the Yalong and Yellow Rivers in Sichuan and Qinghai Provinces (Map 1). In the late $20^{\text {th }}$ century, members of these populations still were living in encampments, engaging in cooperative herding, and managing their pasturelands collectively ${ }^{6}$. Their households were still deriving nearly all their income from production and trade in animal products, and had only limited involvements in the then-nascent market economy ${ }^{7}$. They had, however, been subject to government policies aimed at reducing herd sizes through inducements or requirements for increased sales and slaughter of animals for household use. These policies varied over time and from region to region and were rescinded following natural disasters that resulted in animal losses (Goldstein \& Beall 1990, p. 174, Hopping et al. 2016, Horlemann 2002, p. $261^{8}$ ).

9 The account that follows derives from three projects conducted over a seven-year period. All three projects relied on a semi-structured, household-based interview, 
interviews with community members, and discussions concerning community characteristics with county officials. In 1994, I spent the summer and autumn in Serthar (Ch. Sèdá) and the summer of 2001 in Dzachuka (Ch. Shíqú), two adjacent counties in the northern and northwestern parts of Kandze Tibetan Autonomous Prefecture, Sichuan Province. Serthar, which was created in 1961 by joining high altitude grasslands with a lower altitude, culturally distinct region occupied by farmer herders, had a total population of 34853 in 1990, 24286 of whom were pastoralists. Dzachuka was almost exclusively pastoralist; it is, by area, the largest county in Kandze Prefecture - with the lowest population density - and included 61991 people in 1997. In the summer of 1997, I also conducted a brief term of research in the pastoralist counties of Jigdril (Ch. Jiǔzhi) and Matod (Ch. Măduō) in Golog Tibetan Autonomous Prefecture in Qinghai Province9. These counties included 15400 and 7900 people, respectively, in $1995^{10}$. The interviews were conducted in summer and autumn encampments, located at altitudes between 3600 and $4500 \mathrm{~m}$.

Map 1. Map of study area

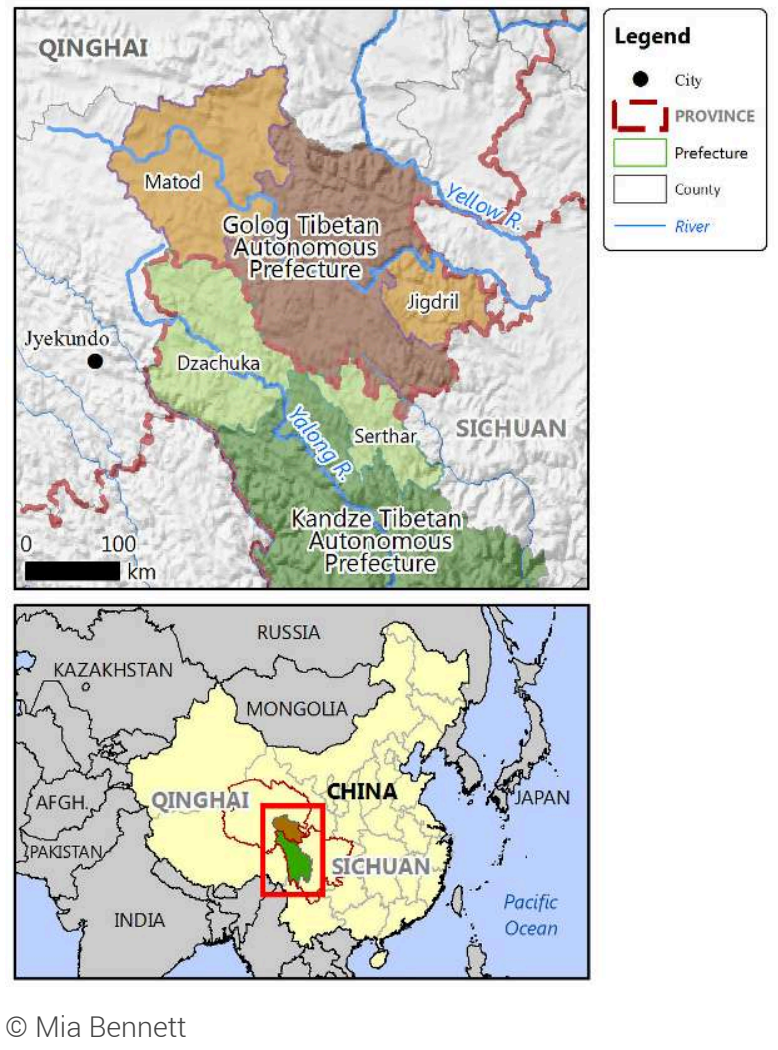

10 The pastoralists in Serthar, Dzachuka, and Jigdril are predominantly cattle keepers. Nearly all of their cattle are yak (g.yag), the females known as dri ('bri), a species suited to the cold, high altitude environment of the Qinghai-Tibetan Plateau, and a few yakcattle crossbreeds in lower-lying regions. Many household herds also included sheep and a few goats. In Matod, which is higher in altitude and receives less precipitation than the other counties, sheep were more numerous and owned by every household with whom I met. In addition to discussions with county officials and community members, I interviewed members of 59 households in Serthar, 29 households in Dzachuka, and six households each in Jigdril and Matod. These interviews focused on 
household membership, herd composition and management, and income and expenditures ${ }^{11}$.

\section{A productive symbiosis}

11 Common sense suggests that subsistence pastoralists have to balance their household's needs and workforce against the productive capacity and needs of their herds, and this is a point that has been reiterated in studies of these populations across cultures and historical periods. Stenning, in his now-classic account of cattle herders in northeastern Nigeria, described pastoralists seeking to attain and sustain a viable balance between the size of their herds and the workforce available to manage the animals. This dynamic balance, which he termed household viability, is easily disrupted when herders are too few to cope with their cattle or cattle are too few to feed the humans that depend on them (Stenning 1958, pp. 100-101). Barth adopted this model to make sense of household reproduction in his influential study of Iranian pastoralists (Barth 1961, p. 18). Tibetan pastoralists also have to balance the size of their herds with household labour, as Bauer (2004, p. 33) noted, and while many may have dreamed of animals beyond counting grazing on nearby hillsides, they undoubtedly recognized that such dreams were impractical. Independent household production required two or more herders, typically adult men and responsible boys and girls, to take their yaks, calves, and sheep out to separate pastures in the morning and lead them home in the evening; herding tasks also were shared with fellow encampment members (Næss 2004, p. 55). Each household needed its own women to milk the dri once or more daily and produce butter, cheese and yoghurt ${ }^{12}$. Women also were responsible for collecting and drying yak dung intended to be used as fuel. These tasks and the care of animals lasted throughout the day, regardless of weather, and could not be set aside. Simple technologies have eased milk processing, notably the stainless steel milk and cream separators that replaced wooden churns and animal stomachs in the 1970s in these areas, but still the workday was long, particularly in summer and early autumn (Goldstein \& Beall 1990, pp. 87, 108-113).

Maintaining a viable balance was an ongoing challenge. Herds grow due to natural increase and sometimes dwindle in response to unfavourable conditions of various kinds. The size of the household and number of workers periodically change as well, due to births, deaths, illnesses, and marriages. Rinzin Thargyal applied the concept of viability in his reconstruction of the lifeways of pre-modern, dependent Dege pastoralists. There, he found, many households suffered crises of viability, due both to shortages of animals and shortages of workers (2007, pp. 131-41).

If, indeed, household viability had been a guiding goal in pastoralists' decision-making, then government policies have rested on flawed models. The longstanding assumption has been that ethnic Tibetan pastoralists value large herds for social and cultural reasons and as a symbol of their wealth and that these values have led them to increase their stock beyond limit and beyond the carrying capacity of their grazing lands ${ }^{13}$. Such assumptions have been called into question by academic studies that identify the complex considerations affecting herd sizes. Among the factors informing the decisions that Tibetan pastoralists make about their livestock are rates of maturation, the need for insurance against disasters, land availability, and land quality (Yeh et al. 2017, Yonten Nyima 2014, p. 189). The availability of workers is a critical factor in this 
labour-intensive production system, as indicated by one elder quoted by Yonten Nyima: "[...] we say we serve the livestock rather than manage them. A good pastoralist should be one who gets up when the livestock get up and sleeps when the livestock sleep" (Yonten Nyima 2014, pp.189- 91). These accounts support the view that Tibetan pastoralists engaged in full-time herding have the aim of achieving viability, rather than the unregulated expansion of their herd animals. They focus on meeting household needs rather than profits, as one would find in industrial ranching ${ }^{14}$.

In the past and at present, Tibetan pastoralist households have used a number of strategies to handle threats to viability caused by shortages of workers or shortages of animals. Some encampments included households, related or not, with complementary imbalances. Those who were rich in livestock but poor in labourers would camp alongside others who had an excess of workers but insufficient animals for their needs, and the poorer households would work for the wealthier ones (Lobsang Gelek 2002a, p. 7). Households with too many animals to manage sometimes hired people who had none. Divorced men or women with young children might camp alongside their siblings or bring a close family member into their households in order to cover the full range of herding tasks. People who were divorced or widowed also might remarry to keep their households viable.

Shortages of animals could be remedied by taking on formal animal loans: for loans of milk cattle this entailed annual payments of butter (Rinzin Thargyal 2007, pp. 103-515). Some of my interviewees who had suffered major losses of livestock from disastrous blizzards purchased replacement animals, as will be discussed below. Possibly the most common way of dealing with animal shortages in past times was raiding more fortunate groups (Ekvall 1968, p. 41).

The literature on Tibetan pastoralists speaks of herding families with very large animal holdings. Ekvall mentioned wealthy pastoralists "possessing two- or three-hundred bovines and a thousand sheep or more" (Ekvall 1968, p. 19). Recollections of premodern times that I collected in Serthar suggest that some local chiefs kept hundreds of cattle which they managed with the aid of servants. These are clearly exceptional cases. The intensive nature of nomadic pastoralism on the high plateau, the time-consuming nature of dairying in particular, makes large herds impractical for most people most of the time. Instead, I found households whose members were dedicated to the care of their small-to-moderately sized herds.

In order to determine whether there was a close match between a household's membership and the size of its herds, as the classic model of household viability predicts, I included questions on both sets of topics in Serthar and Dzachuka. And I did find a strong and significant relationship between the cattle held by the pastoralists whom I interviewed and their household's size and its workforce, here defined as adults aged 16 through 64 (Table $1^{16}$ ). I expected that the relationship between numbers of milk animals and female workers would be stronger than the relationship between milk animals and workers generally, but this expectation was not met. Thus it seems that the size of the household workforce overall had more of an impact on the number of milk animals than the number of women available for milking and milk processing. These relationships are weaker for small stock, that is, herds consisting of mostly sheep and a few goats. For Serthar, there was a moderately strong relationship between the numbers of sheep and goats a household owned and its size and workforce. For Dzachuka, by contrast, the relationship was small to non-existent. The reasons are 
unclear. One might think that losses of these animals in the blizzards that occurred prior to my research (discussed in greater detail below) played a role. However, the Dzachuka households whose members I interviewed reported similar losses of cattle and small stock and were far closer to rebuilding their cattle herds - despite the lower rates of natural increase among cattle. More likely, these numbers reflect the general retreat from sheep herding that was occurring in eastern Tibetan regions at this time. Sulek found that sales of sheep increased in Golog's Machen County after 2000 (Sulek 2011, pp. 14-15). The individuals she surveyed explained these sell-offs by lack of labour, insufficient grassland resources, the harsh climate that made it difficult for lambs to survive, and vulnerability to predation by wolves, to which she added the increasing profits from caterpillar fungus ${ }^{17}$. Additionally, the patchwork of fences that was springing up across the countryside and complicating travel to remote terrain may have made it more difficult to keep sheep (Bauer 2005). Faced with these problems, it seems that many eastern Tibetan pastoralists decided to sacrifice their sheep in order to concentrate on maintaining their yaks (Sulek 2011, p. 19).

Table 1. Relationships between households and their herds: Pearson's correlation

\begin{tabular}{ccc}
$\begin{array}{c}\text { N. of } \\
\text { Household } \\
\text { Members }\end{array}$ & $\begin{array}{c}\text { N. of } \\
\text { Household } \\
\text { Workers }\end{array}$ & $\begin{array}{c}\text { N. of Adult } \\
\text { Women }\end{array}$ \\
\multicolumn{2}{c}{ Pearson Product-Moment Correlations }
\end{tabular}

\begin{tabular}{|c|c|c|c|c|c|c|}
\hline \multicolumn{7}{|l|}{ N. of Cattle } \\
\hline Serthar & 0,52 & $* * *$ & 0,61 & $* * *$ & 0,51 & $* * *$ \\
\hline Dzachuka & 0,59 & $* * *$ & 0,56 & $* *$ & 0,48 & $*$ \\
\hline \multicolumn{7}{|l|}{ N. of Milk } \\
\hline \multicolumn{7}{|l|}{ Animals } \\
\hline Serthar & 0,51 & $* * *$ & 0,62 & $* * *$ & 0,53 & $* * *$ \\
\hline Dzachuka & 0,56 & $* *$ & 0,58 & $* *$ & 0,44 & $*$ \\
\hline \multicolumn{7}{|l|}{ N. of Sheep } \\
\hline Serthar & 0,45 & $* * *$ & 0,44 & $* * *$ & 0,38 & $* *$ \\
\hline Dzachuka & 0,23 & & 0,01 & & 0,05 & \\
\hline \multicolumn{7}{|l|}{ N. of Cases } \\
\hline Serthar & 58 & & & & & \\
\hline Dzachuka & 28 & & & & & \\
\hline \multicolumn{7}{|l|}{$*=p<0,05$} \\
\hline \multicolumn{7}{|l|}{$* *=p<0,01$} \\
\hline$* * *=p<0,001$ & & & & & & \\
\hline
\end{tabular}

\section{Losses of animals: snow disasters}

There is no more serious threat to the viability of a pastoralist's household than losses of its animals, whether from displacement, natural disaster, disease, or predation. In the late $20^{\text {th }}$ century, climatic events posed the most serious risk ${ }^{18}$. Southern Qinghai and northwestern Sichuan Provinces were particularly vulnerable to what the popular press and scholarly literature came to call "snow disasters". This term refers to heavy winter snowfalls, sometimes followed by thaws and refreezing, which create ice on the snow that prevents livestock from reaching forage for prolonged periods of time. The 
result has been high mortality for animals that rely more or less exclusively on open range grazing and that are already stressed by long, cold winters and poor-quality forage (Wu \& Yan 2002, pp. 4-7, Yeh et al. 2014, p. 64). The winter of 1996 marked the worst disaster on record for eastern Tibetan regions. Devastating losses of animals were reported for the Jyekundo (Ch. Yùshù) area of Qinghai Province. Reports from that time speak of pastoralists feeding their grain supplies to their animals to try to save them (Miller 2000, p. 88, Wu \& Yan 2002, Zhaluo 2013, p. 204). The 1996 snow disaster was followed by a second crisis in 1998. That winter, heavy snowfalls and intensely cold temperatures affected an area extending from Jyekundo and environs to neighbouring areas of the Tibet Autonomous Region. The central government responded to both crises with its own humanitarian relief efforts, food and clothing for the pastoralists, and feed for their animals, aided by a number of international nongovernment organizations (Tibet Information Network 1998, pp. 65-66, Miller 2000).

19 The severe weather also affected neighbouring counties. When I visited Dzachuka County in 2001 and Matod County in 1997, I asked householders for their recollections of the massive 1996 snow disaster and descriptions of how it had affected their lives and livelihoods ${ }^{19}$. The events of those winters were vivid in people's minds. Pastoralists in Dzachuka recalled the succession of heavy snowfalls in 1996, five years previously, and how they were followed by thaws and then low temperatures, resulting in sheets of ice sandwiched between thick layers of snow. The storms were so severe that wild animals, gazelles, antelope, deer, and blue sheep, came down from the hills seeking grass and were so weak that they died at the doors of pastoralists' tents. Their own animals could not break through the ice and died from starvation and exposure. And many of the pregnant females that did survive gave birth to dead calves, lambs, kids, and foals that spring. Dzachuka County officials estimated that the number of domestic animals declined by $64,8 \%$ during the decade of the 1990 s, largely due to the succession of snow disasters ${ }^{20}$. My time in Serthar also followed a severe snow disaster by two years, during which $23,4 \%$ of the county's domestic animals had died. Such high levels of mortality came to be seen by many officials as proof of the fundamental irrationality of pastoralism on the Tibetan Plateau and informed plans to introduce more "modern" and "scientific" animal husbandry practices, including houses, barns, fencing, and more economically rational herd compositions (Miller 2000, p. 84).

20 Pastoralists, nonetheless, had their own strategies to reduce losses of animal in severe weather, mostly strategies involving mobility. Many used to take their herds especially sheep - on lengthy treks to remote, high altitude areas in late summer and autumn to fatten them up and, after a major snowfall, to high, windswept, south-facing valleys where forage might be available. Such travel had become more complicated by the late 1990s, due to more carefully drawn regional boundaries and the erection of new fences to protect contracted-out grazing land. Zhaluo has described how chiefs in the pre-modern era negotiated the temporary transfer of animals from regions hit by heavy snowstorms to disaster-free areas, with compensation provided to the receiving group, and noted that some regions had reciprocal agreements of this kind (Zhaluo 2013, pp. 206-207). In recent years, the government has sponsored similar transfers (Yeh et al. 2014, pp. 65, 67, 71), as well as coordinated relief efforts (Zhaluo 2013, pp. 209-211).

21 I visited Matod just over a year after the 1996 snow disaster. Members of the six households I was able to interview all were substantial herd owners and described 
losing between sixty and seventy yaks (averaging $51 \%$ of their pre-blizzard herds), between two hundred and six hundred sheep, and two to four horses. They too reported many stillborn animals and other newborns that swiftly died. Nonetheless, little more than a year later, they were actively engaged in re-growing their herds. This was mostly a matter of natural increase: there were a small number of calves that survived in the spring of 1996 and a larger number born in 1997. These households also had used available cash to purchase adult female cattle. One such household described purchasing four dri; another had purchased eight. A third household had sold eight male yaks and then turned around and used the profits to buy 20 dri. What this small sample of households shows is that pastoralists pursue strategies to enable them to maintain viable herd sizes and pragmatically manipulate sales and purchases of animals to do so.

\section{Animals set apart: tsetar}

22 I begin this section with an instructive comparison: early $20^{\text {th }}$ century anthropologists attempts to make sense of East African pastoralists' herd management practices and the debates their studies sparked. Those accounts highlighted the centrality of cattle across the cultural landscape, their place in local cosmologies, and the role cattle played in social transactions and status ranking. They also highlighted the affection that men displayed toward their animals and their seeming reluctance to slaughter them (Evans-Pritchard 1940, Herskovits 1926). In all, cattle ownership among East African peoples was construed as conveying prestige more than prosperity, and love of cattle was stressed over their economic role in provisioning families. This literature subsequently was criticized for the ways in which it exoticized pastoral peoples, exaggerated the non-utilitarian dimensions of cattle keeping, and neglected women's perspectives. The critiques turned the earlier arguments on their head by showing the rationality of these sorts of cattle-keeping practices under prevailing political constraints and the ways in which herd management provided a kind of economic infrastructure for cultural beliefs and values (Barfield 1993, pp. 20-26, Levine 1999, pp. 161-162). Flawed though they may be, the early anthropologists' portrayals of the intensity and complexity of pastoralists' relations with their animals remain convincing. As they show and as the growing literature on multi-species relationships makes clear, the lives of herders and their animals are multiply intertwined and mutually implicated, and their close, lifelong association involves a mix of attitudes pragmatic, symbolic, and emotional in equal measure. This is an observation as relevant to Tibetan pastoralists in China as to their counterparts anywhere in the world and as relevant to pastoralists in past times as to those still engaged in full-time animal husbandry in the modern day.

One feature of Tibetan herd management that both complicates and enriches our understanding of multi-species relationships is the selection of certain animals as tsetar (tshe thar), literally, "liberated lives". An animal so designated is exempted from slaughter, left to freely roam or follow its herd mates, and to die a natural death. There are no prohibitions against milking tsetar animals, shearing tsetar sheep, and cutting or combing the hair of tsetar yaks. People also may eat these animals after they die, but killing them is absolutely proscribed. Anyone who kills such an animal brings serious criticism on his head and a grave risk of bad fortune on himself and his household. 

throughout Buddhist Asia. For Tibetan societies, these practices have deep historical roots, are common in farming and pastoral areas, and are supported by textual rituals (Holler 2002, p. 207). In addition to tsetar, pastoralists also may consecrate animals to local places or mountain deities. These animals - known as lha'i gyag and lha'i lug - also may roam freely and are exempt from slaughter (see Tan 2016 on the Minyak region). All such practices were suspended during the collective period, when animals were managed under a centrally planned economy and religious expression was suppressed, but were revived when independent household production resumed (Gaerrang 2017, p. 3). although their numbers and species varied according to the household's particular circumstances. I asked for a tally and for the circumstances of the animals' selection and found that the most common reasons for consecrating a tsetar were the illness or death of a household member. The stated hope was that extending the animal's life would help that person recover and live a long life or avoid rebirth in the hell realms suggesting that the trajectories of animal and human lives could intersect (Barstow 2017, p. 81) Some people also described the consecration of tsetar as a counter to the sorts of karmic obstacles (bar chad) that are held to weigh on the living and contribute to misfortunes of various kinds or as a way of enhancing the welfare of the household, including its economic fortunes and the growth of its herds. Others stated that consecrating tsetar provided religious merit or enacted compassion for animals. Speaking analytically, designating an animal as a tsetar can be seen as the opposite of the kind of ritualized animal sacrifice that involves slaughtering an animal - a common practice in many parts of the world. Yet, in another sense, tsetar and animal sacrifice have similar goals in redressing negative transcendental forces and have comparable expectations of the chosen animal, who stands in for its owner-household members, benefits them by the fact of its slaughter or liberation, and thus mediates boundaries between human and non-human realms ${ }^{21}$. In his auto-ethnographic account, Chos bstan rgyal writes that people imagine their tsetar animals safeguarding their progress in their intermediate state after death and their passage to a better rebirth (Chos bstan rgyal 2014, p. 174). I have heard similar accounts ${ }^{22}$. Such practices and imaginings throw into sharp relief the poverty of anthropological divisions between nature and culture and highlight the importance of accommodating both human and non-human organisms in a unified domain of sociality (da Col 2012, p. 76).

The consecration of tsetar was typically preceded by consultation with a lama skilled at conducting one of the many available forms of divination - through using a rosary, the scapula of a sheep, dice, his own clairvoyance, or an astrological text - in order to determine how to offset the forces contributing to household members' misfortunes, illnesses, and shortened lives. The lama might advise the release of one or more household animals to create spiritual merit and counter, for example, the bad karma that its members had accrued by a lifetime of sins, including slaughtering animals for meat and selling animals for slaughter, and thus transform a person's fate.

People explained their choice of a tsetar by what we might describe as gratitude toward or bonding to a particular animal. Commonly chosen were animals that had made an economic contribution to the household, such as a dri that had been a good milk producer or a ewe that had produced many offspring (see also Chos bstan rgyal 2014,

Études mongoles et sibériennes, centrasiatiques et tibétaines, 50 | 2019 
p. 134). Another likely choice was an animal regarded with special affection by household members, such as a mild-tempered, hornless yak that had been ridden for many years. Killing animals that had contributed so much was, in the words of one respondent, insupportable. In his autobiography, Naktsang Nulo offered the example of orphaned lambs that were hand-raised and sometimes kept in the tent until they could manage by themselves (Naktsang Nulo 2014, p. 66). Another typical selection was an especially handsome animal which had unusual coloration and beautiful horns. The latter are the sorts of animals that are thought to contribute to the household's stock of good fortune (g.yang) and contribute to its members' wealth, well-being, and efficacy ${ }^{23}$. In other words, householders were likely to select as tsetar the sorts of animals they were least likely to slaughter - in the near term any way. Lamas called in to advise on such matters might try to guide the household into what they perceived to be a more virtuous choice - to select an animal that was old, of little worth, and at risk of being slaughtered. The selection was confirmed by a brief ritual, and the chosen animal was marked by a tassel in its ear or colourful strips of cloth tied on its back (Holler 2002, p. 217).

Substantial numbers of herd animals in Serthar and Dzachuka had been consecrated as tsetar. Household interviewees in Serthar and Dzachuka respectively described 21 and $22 \%$ of their cattle as tsetar. The percentages were even higher for sheep: $42 \%$ in Serthar and 26\% in Dzachuka (Table 2). In several instances, household respondents described all their sheep as tsetar. These numbers are higher than I had expected from the limited literature, which offers such figures as 8 to $10 \%$ of the herd or ten animals per household (Chos bstan rgyal 2014, p. 172, Holler 2002, p. 222). What could account for these surprising results? One possibility is that people cited high numbers of tsetar as a form of resistance against potential or actual urgings from the government to bring more cattle and sheep to market - given that any animal designated as tsetar is exempt from sale. Another possible reason was the frequent experience of snow disasters in the 1980s and 1990s. These events may have reinforced ideas about keeping larger herds to provide a reserve or a form of insurance to restock and recover (Levine 1999, p. 162, Yonten Nyima 2014, pp. 189-190). It also is possible that the responses I collected were exaggerated and indications of hopeful intentions more than reality. If so, such thinking may have been a precursor to support for the anti-slaughter movement that took shape several years later, in which eastern Tibetan pastoralists responded to charismatic Buddhist teachers' appeals by pledging not to sell any of their animals or slaughter them for meat (Gaerrang 2011, 2017). 
Table 2. Tsetar in household herds

Serthar, 1994 Dzachuka, 2001

$\begin{array}{lrr}\text { Average: } & & \\ \text { N. of Cattle } & 58,2 & 50,7 \\ \text { N. of Tsetar Cattle } & 12 & 11,2 \\ \text { Pct. of Cattle Herd } & 21 & 22 \\ \text { N. of Cases } & 38 & 26 \\ & & \\ \text { N. of Sheep } & 20,9 & 33 \\ \text { N. of Tsetar Sheep } & 8,7 & 8,7 \\ \text { Pct. of Sheep Herd } & 42 & 26 \\ \text { N. of Cases } & 38 & 26\end{array}$
economically from those animals. They could not sell or slaughter them, although they could consume the products of their milk, shear them, use their hair in tents and ropes, and sell their skins when they died a natural death. They also could profit from these animals' offspring. For the pastoralists who kept tsetar, there were other benefits which were less determinate or quantifiable than the price to be had from market sales. That is, the important protections that tsetar were held to provide against bad fortune in everyday life and in the hereafter. From an observer's perspective, tsetar conveyed other practical benefits too, which may or may not have been explicitly acknowledged. For one, owning numbers of such animals enhanced a household's reputation in its community, in that tsetar were both a display of wealth and a display of virtue in a religious sense (Rinzin Thargyal 2007, p.75). They also demonstrated household members' competence in herd management. As one Dzachuka man told me: "Successful households take care of and do not slaughter or sell many animals. Unsuccessful households don't take care; they sell and slaughter many animals". Thus tsetar can be seen as having enhanced both the spiritual and social capital of the households that kept them.

The intention to exempt favoured animals from slaughter was also grounded in a world view in which pastoralists projected human emotions onto domestic animals and the capacity of those animals to feel pain and sorrow and fear death. Such ideas can be seen in the lyrics of popular songs in the past and at present (Gaerrang 2011, p. 35, Namkhai Norbu 1997, p. 40) and in present-day literature (for example, the first chapter of Chos bstan rgyal 2014), as well as in religious commentaries (Barstow 2017, pp. 19, 73-76). Fijn (2011, p. 47) argued that Mongolian pastoralists view animals as capable of expressing feelings and emotion, that they ascribe to each individual animal recognizable characteristics and a distinct personality, and, akin to the Tibetan pastoralists described here, "view themselves as being in a reciprocal relationship with the animals they herd, such that if the herding family works hard to nurture and provide for the animals then in turn the herd animals will nurture and provide for the herding family".

Clearly, however, different categories of animals have had different claims on people's attention and compassion. Ekvall, who spent time with eastern Tibetan pastoralists early in the $20^{\text {th }}$ century, mentions the reluctance to slaughter animals and the ethical dilemmas raised by killing, but notes that these concerns did not extend to offspring of 
the yak-cattle crossbreeds known as dzomo that were kept in some encampments and were slaughtered without compunction or prevented from nursing and died of starvation (Ekvall 1968, pp. 46-47, see also Rinzin Thargyal 2007, pp. 82-83). Sheep, as noted above, also have had a lesser claim on eastern Tibetan pastoralists' sympathies than cattle do, although ewes that have produced many offspring may be protected and were favoured as tsetar animals. People also apparently have no qualms about hunting wild animals for food and are keen to kill predators that prey on herd animals, such as wolves (Huber 2012, p. 209, Næss 2004, pp. 79-83). On the other end of this continuum of solicitude for animals are horses, which receive supplementary food and are blanketed in winter, given special attention because of their perceived vulnerability, cost, prestige value, and undoubtedly because of the close bonds and communication that develop between riders and their horses. Because horses are never slaughtered, they do not need the protection of being made tsetar.

\section{Conclusions}

This paper uses a data set from the late $20^{\text {th }}$ century, a time when eastern Tibetan pastoralists experienced their lives through the daily round of care for domestic animals and the processing of animal products, to explore the multiple dimensions of thinking about and actions toward those animals. It is hardly surprising that animals kept lifelong in privately owned small herds should become the focus of complex and sometimes conflicting attitudes and emotions, ranging from pragmatic concerns with managing them to support the needs of the human household, to concerns to nurture animals, protect them against predators and natural disasters, and avoid unnecessary slaughter, and, finally, to gratitude and affection. The fact that Tibetan pastoralists express such sentiments should not be overlooked because planners and development agents seize on them as symptomatic of a fundamental irrationality. Working effectively with living animals involves adaptability and sensitivity to their needs, and pastoralists often put aside their own comfort to tend to the welfare of their animals. And the ability of Tibetan pastoralist populations to maintain healthy herds in highly challenging physical and political environments speaks to the effectiveness of their practices.

33 These multi-faceted commitments to the welfare of animals, so critical to effective herd management, are summed up in the prayer that one of my interviewees recalled his mother reciting every evening in past times:

No matter the degree of my virtue, it is dedicated to purify the negative karma of cursing; to purify the sins of my hands; to purify the killing of animals before this tent; for all the meat I have consumed and the yogurt and milk that I have drunk. For the dog at the gate and the horses that transport us along with the yaks. May they all derive benefit from this dedication!

It goes without saying that new studies on relations between pastoralists and herd animals are merited, given the major socio-economic changes that have occurred in the intervening years. Modern education, greater integration in markets, mechanized transportation, and new livelihoods have surely affected attitudes toward these animals. It would also be useful to see how ideas about animal-human relationships differ by age and gender, by residence and occupation, and among pastoralists who are and who are not committed to the anti-slaughter movement. 
In closing, this paper is meant, first, as a contribution to Tibetan studies. It describes the ways in which household conditions, environments of risk, and policy constraints influenced the decisions that pastoralists made regarding their animals. This paper also addresses issues raised by expanding anthropological efforts to comprehend the ways in which the lives of humans and animals are mutually implicated. Here I have attempted to provide a multifaceted look at a multi-species encounter in which dimensions of human experience affected attitudes and actions concerning domestic animals. A third aim is to analyse the intersecting logics informing herd management strategies, that is, how the pragmatic calculus of household viability, cultural-religious values in the case of tsetar animals, and the affective attachments that pastoralists had to particular animals affected the size and composition of herds.

\section{BIBLIOGRAPHY}

Barfield, T. J. 1993 The Nomadic Alternative (Englewood Cliffs, N. J., Prentice Hall).

Barstow, G. 2018 Food of Sinful Demons. Meat, Vegetarianism, and the Limits of Buddhism in Tibet (New York, Columbia University Press).

Barth, F. 1961 Nomads of South Persia. The Basseri of the Khamseh Confederacy (Boston, Little Brown).

Bauer, K. 2004 High Frontiers. Dolpo and the Changing World of Himalayan Pastoralists (New York, Columbia University Press).

2005 Development and the enclosure movement in pastoral Tibet since the 1980s, Nomadic Peoples 9(1-2), pp. 53-81.

Bauer, K. \& Yonten Nyima 2010 Laws and regulations impacting the enclosure movement on the Tibetan Plateau of China, Himalaya 30(1-2), pp. 23-37.

Breuer, I. \& A. Gruschke 2016 Tibetan livelihoods and the "great development of the west". Modernization, pastoral resources, and the "urban future" of the grasslands, China Tibetology 2, pp. 3-18.

Chos bstan rgyal, edited by G. Roche 2014 Following the herds. Rhythms of Tibetan Pastoral Life in Amdo, Asian Highlands Perspectives 32, pp. 1-212.

Col, G. da 2012 The elementary economies of Dechenwa life. Fortune, vitality, and the mountain in Sino-Tibetan borderlands, Social Analysis 56(1), pp. 74-98.

Ekvall, R. B. 1968 Fields on the Hoof. Nexus of Tibetan Nomadic Pastoralism (New York, Holt, Rinehart and Winston).

Evans-Pritchard, E. E. 1940 The Nuer. A Description of the Modes of Livelihood and Political Institutions of a Nilotic People (Oxford, Oxford University Press).

Fijn, N. 2011 Living with Herds. Human-animal Coexistence in Mongolia (Cambridge, Cambridge University Press).

Fischer, A. M. 2005 State Growth and Social Exclusion in Tibet. Challenges of Recent Economic Growth (Copenhagen, NIAS Press). 
Gaerrang (Kabzung) 2011 The alternative to development on the Tibetan Plateau. Preliminary research on the anti-slaughter movement, Revue d'Etudes Tibétaines 21, pp. 31-43.

2015 Development as entangled knot. The case of the slaughter renunciation movement in Tibet, China, Journal of Asian Studies 74(4), pp. 927-951.

2017 Contested understandings of yak on the eastern Tibetan Plateau. Market logic, Tibetan Buddhism and indigenous knowledge, Area [online, URL: http://onlinelibrary.wiley.com/wol1/ doi/10.1111/area.12343/full, accessed 17 June 2017].

Gros, S. 2016 Introduction to "Frontier Tibet. Trade and boundaries of authority in Kham", CrossCurrents: East Asian History and Culture Review 19 [online URL: https://cross-currents.berkeley.edu/ sites/default/files/e-journal/articles/gros_intro.pdf, accessed 6 December 2017].

Gruschke, A. 2008 Nomads without pastures? Globalization, regionalization, and livelihood security of nomads and former nomads in northern Khams, Journal of the International Association of Tibetan Studies 4. [online URL: http://www.thlib.org/collections/texts/jiats/\#!jiats=/04/ gruschke/, accessed 9 January 2018].

Herskovits, M. J. 1926 The cattle complex in East Africa, American Anthropologist 28(1-4), pp. 230-272, 361-388, 494-528, 633-664.

Holler, D. 2002 The ritual of freeing lives, in H. Blezer (ed.), Religion and secular culture in Tibet (Leiden, Brill), pp. 207-226.

Hopping, K. A., Ciren Yangzong \& J. A. Klein 2016 Local knowledge production, transmission, and the importance of village leaders in a network of Tibetan pastoralists coping with environmental change, Ecology and Society [online, URL: https://www.ecologyandsociety.org/vol21/iss1/art25/, accessed 7 December 2017].

Horlemann, B. 2002 Modernization efforts in mGo Log. A chronicle, 1970-2000, in T. Huber (ed.), Amdo Tibetans in Transition (Leiden, Brill), pp. 241-269.

Huber, T. 2012 The changing role of hunting and wildlife in pastoral communities of northern Tibet, in H. Kreutzmann (ed.), Pastoral Practices in High Asia. Agency of "Development" Effected by Modernisation, Resettlement and Transformation (New York, Springer), pp. 195-215.

Levine, N. E. 1998 From nomads to ranchers. Managing pastureland among ethnic Tibetans in northern Sichuan, in G. Clarke (ed.) Development, Society and Environment in Tibet (Vienna, Verlag der Osterreichischen Akademie der Wissenschaften), pp. 69-76.

1999 Cattle and the cash economy. Responses to change among Tibetan nomadic pastoralists in Sichuan, China, Human Organization 58(2), pp. 161-172.

2015 Transforming inequality. Eastern Tibetan pastoralists from 1955 to the present, Nomadic Peoples 19(2) pp. 164-188.

Lobsang Gelek 2002a The Washul Serthar. A nomadic community of eastern Tibet, Chinese Sociology and Anthropology 35(1), pp. 3-20.

$2002 \mathrm{~b}$. The herders of eastern Tibet. Notes from an anthropological field study, Chinese Sociology and Anthropology 35 (1), pp. 21-81.

Miller, D. J. 2000 Tough times for Tibetan nomads in western China. Snowstorms, settling down, fences and the demise of traditional nomadic pastoralism, Nomadic Peoples 4(1), pp. 83-109.

Næss, M. W. 2004 Living with risk and uncertainty. The case of the nomadic pastoralists in the Aru Basin. Candidatus rerum politicarum thesis (Tromsø, Tibet University of Tromsø) [online, URL: https://en.uit.no/Content/72654/Avhandling-Hovedfag.PDF, accessed 7 December 2017]. 
Namkhai Norbu. 1997 Journey among the Tibetan nomads. An Account of a Remote Civilisation (Dharamsala, Library of Tibetan Works and Archives).

Naktsang Nulo 2014 My Tibetan Childhood. When Ice Shattered Stone (Durham, Duke University Press).

Shahrani, M. N. 2002 The Kirghiz and Wakhi of Afghanistan. Adaptation to Closed Frontiers and War (Seattle, University of Washington Press).

Stenning, D. 1958 Household viability among the pastoral Fulani, in J. Goody (ed.), The Developmental Cycle in Domestic groups (Cambridge, Cambridge University Press), pp. 92-119.

Sulek, E. 2011 Disappearing sheep. The unexpected consequences of the emergence of the caterpillar fungus economy in Golok, Qinghai, China, Himalaya 30(1-2), pp. 9-22.

2016 Caterpillar fungus and the economy of sinning. On entangled relations between religious and economic in a Tibetan pastoral region of Golog, Qinghai, China, Études mongoles \& sibériennes, centrasiatiques \& tibétaines 47 [online URL: http://journals.openedition.org/emscat/2769?lang=en, accessed 8 January 2018].

Tan, G. 2016 "Life" and "freeing life" (tshe thar) among pastoralists of Kham: intersecting religion and environment, Études mongoles \& sibériennes, centrasiatiques \& tibétaines 47 [online, URL: http:// emscat.revues.org/2793, accessed 24 June 2017].

Rinzin Thargyal, edited by T. Huber 2007 Nomads of Eastern Tibet. Social Organization and Economy of a Pastoral Estate in the Kingdom of Dege (Leiden, Brill).

Tibet Information Network 1998 News Review. Reports from Tibet, 1997 (London, City Cloisters).

Tsewang Namgail, J. L. Fox \& Y. V. Bhatnagar. 2007 Carnivore-caused livestock mortality in Trans-Himalaya, Journal of Environmental Management 39(4), pp. 490-496 [online, URL: https:// www.ncbi.nlm.nih.gov/pubmed/17318699, accessed 10 December 2017].

Wu, N. \& Z. Yan. 2002 Climate variability and social vulnerability on the Tibetan Plateau. Dilemmas on the road to pastoral reform, Erdkunde. Archive for Scientific Geography 56(1), pp. 2-14.

Wu, N., Z. Yan \& T. Lu 2012 Enclosure and resettlement in the eastern Tibetan Plateau. Dilemma of pastoral development during the last three decades, in H. Kreutzmann (ed.), Pastoral Practices in High Asia. Agency of "Development" Effected by Modernisation, Resettlement and Transformation (Berlin, Springer), pp. 291-306.

Yan, Z., N. Wu, Yeshi Dorji \& R. Jia 2005 A review of rangeland privatisation and its implications in the Tibetan plateau, China, Nomadic Peoples 9(1-2), pp. 31-51.

Yeh, E. T. 2005 Green governmentality and pastoralism in Western China. "Converting pastures to grasslands", Nomadic Peoples 9, pp. 9-30.

Yeh, E. T., Yonten Nyima, K. A. Hopping \& J. A. Klein 2014 Tibetan pastoralists' vulnerability to climate change. A political ecology analysis of snowstorm coping capacity, Human Ecology 42(1), pp. 61-74 [online URL: https://link.springer.com/article/10.1007/s10745-013-9625-5, accessed 11 December 2017].

Yeh, E. T., L. H. Samberg, Gaerrang, E. Volkmar \& R. B. Harris 2017 Pastoralist decision-making on the Tibetan Plateau. Human Ecology [online, URL: http://link.springer.com/article/10.1007/ s10745-017-9891-8, accessed 7 May 2017].

Yin, H., C. Cao, M. Xu, W. Chen, X. Ni \& X. Chen. 2016 Long-term snow disasters during 1982-2012 in the Tibetan Plateau using satellite data, Geomatics, Natural Hazards and Risk, [online, URL: 
http://www.tandfonline.com/doi/abs/10.1080/19475705.2016.1238851, accessed 5 December 2017].

Yundannima 2012 From "retire livestock, restore rangeland" to the compensation for ecological services. State interventions into rangeland ecosystems and pastoralism in Tibet. $\mathrm{PhD}$ thesis (Boulder, University of Colorado, cited with permission).

Yonten Nyima 2014 A larger herd size as a symbol of wealth? The fallacy of the cattle complex theory in Tibetan pastoralism, Area 46(2), pp. 186-193.

Zhaluo, 2013. Snow disasters and relief efforts. A case study in Tibetan pastoral areas in southern Qinghai, in L. Wang \& L. Zhu (eds), Breaking Out of the Poverty Trap. Case Studies from the Tibetan Plateau in Yunnan, Qinghai and Gansu (Hackensack, N. J., World Century Publishing), pp. 201-227.

\section{NOTES}

1. The spelling of Tibetan terms in the text is meant to match local pronunciation as closely as possible. Tibetan terms in parentheses follow their classical spellings, transliterated using the Wylie system. Chinese terms and place names are given in pinyin and are prefaced by the abbreviation "Ch.".

2. While the occurrence of severe weather has varied regionally from year to year, there were extremely severe blizzards across large areas of the Tibetan Plateau in 1983, 1985, 1997, 1998 and, on a smaller scale, in 2008 (Yin et al. 2016).

3. In many instances, people remained on the same lands that their local groups had utilized in the collective era and in traditional times. In some cases, however, groups were transplanted to different regions (see Levine 1998, p. 72).

4. Integrated pastoralist development programs involving three to five components were implemented throughout these areas, in connection with the distribution of land contracts (see Gruschke, 2008, Horlemann 2002, p. 251, Levine 2015, p. 178, Wu et al. 2012, p. 298). As Yeh and Miller have noted, privatization and fencing of pasture were meant to enhance productivity and environmental stewardship (Yeh 2005, pp. 17, 25, Miller 2000, pp. 103, 106). The relative costs versus benefits and the impact of these policies on intra-group cooperation and sociality, however, are unclear.

5. In many regions, pastoralists have sold herd animals in order to purchase a house (see Gaerrang 2011, p. 38, Levine 2015). This process was underway as early as 2001 in Ngaba County (Ch. Ảbà Xiàn), where three of the five householders I interviewed described having sold substantial numbers of cattle and sheep in order to pay for "modern" (concrete) houses, barns, and fencing for their contracted one-season pasturelands.

6. The distribution of land contracts in this region occurred in and around the year 1997. While all the households interviewed for this paper were grazing their animals collectively year-round, the households in one township that I surveyed in Dzachuka had constructed fenced-in reserve pastures in 1998.

7. The pastoralists in the study regions recalled traveling annually to sell pastoralist products and buy subsistence goods at trading centers such as Kandze and towns in Dzachuka and Darlag Counties, but were not participants in larger, cross-regional trading networks (described by Gros 2016). Nor was trade in caterpillar fungus a major component of household incomes. On traditional pastoralists' annual trading trips, see Rinzin Thargyal (2007, pp. 95-99).

8. Hopping reports pastoralists who exceeded their quotas being fined under then-existing herd reduction policies (Hopping 2016; personal communication). In Serthar, by contrast, pastoralists described being urged to reduce their herds by a stipulated $11 \%$ in 1994 , but no coercive measures to enforce such a policy (Levine 1999, p. 165). In Matod, interviewees described the 
government having reduced taxes (sha khral) in 1997, in response to herd losses in the 1996 snow disaster. These examples highlight the great variation in such policies and how they were applied. More recent years have seen new policies aimed at herd reduction. One is the "Rangeland Ecological Protection Reward Mechanism" (Ch. caoyuan shengtai baohu jiangli jizhi), which has been implemented at different times in selected different locations across the Tibetan Plateau and involves the payment of subsidies to pastoralists who do not exceed their livestock quotas.

9. In traditional times, Dzachuka was subject to and paid taxes to Dege, although the administrative presence was minimal. The pastoralist regions of Serthar and most Golog areas, by contrast, remained autonomous. All three areas came under the control of the People's Republic of China between 1950 and 1952 (see Horlemann 2002, pp. 246-247 on Golog).

10. While such government statistics should be treated with caution (Fischer 2005, pp. 6-12), numbers gleaned from limited distribution documents can offer some insights into the balance of herd animals and changes in their numbers over time. According to such records there were 222267 cattle, 125887 sheep and goats, and 17821 horses in Serthar in 1993 and 300102 cattle, 308511 sheep and goats, and 23064 horses in Dzachuka in 1997. For Serthar this was a decline of 11\% over the 1983 figures, while for Dzachuka there was a reported 35\% decline between 1988 and 2000. Government officials in both counties attributed the declines to snow disasters and grassland degradation. Statistics published for 1995 in Golog Tibetan Autonomous list 244400 cattle, 142100 sheep, and 10700 horses in Jigdril and 110000 cattle, 301800 sheep and goats, and 5300 horses in Matod.

11. While pastoralists keep careful track of their own animals on the daily round and on seasonal migrations (Chos bstan rgyal 2014, pp. 13-14), concerns about how I might use the numbers may have led to underreporting. There is less reason to expect misreporting of household membership, and, in Serthar, I was able to cross-check these data against local township censuses. I did find apparent discrepancies in reports of income and expenditures: claims of greater expenditures (for town-bought goods and foods) than income (primarily from the sale of animal products and some sales of medicinal herbs).

12. I was given the following rules of thumb: one woman can easily milk and process the milk of twenty-five to thirty dri. Some women can manage more, but not beyond fifty dri. A herder can supervise between seventy and more than one hundred cattle, but only twenty calves, which are much more difficult to control than adult animals. One person can handle a herd of two hundred sheep.

13. (Yonten Nyima 2014) described these ideas under the rubric of the "cattle complex theory" in China.

14. It should be noted that the distribution of animals at the outset of the household responsibility system accommodated concerns with viability. In most areas, each household received shares of the collective's animals according to the size of its membership. In Serthar, active adult workers received an additional share.

15. None of the householders I interviewed mentioned having animals on loan, although I did hear of monastic institutions receiving donations of animals and having those animals managed by local herders. Ethnographies of other Central Asian groups have described various systems of contract rentals for animals (Barth 1961, pp. 13-14, Shahrani 2002, pp. 179-181). This practice also existed among Tibetan speaking agro-pastoralists in northwestern Nepal.

16. This table relies on use of the Pearson Correlation Coefficient, which measures the strength of the relationship between two variables and whether this relationship can be considered statistically significant, that is, not due to chance. Positive relationships for this statistic range from 0 to 1 , with relationships of 0,5 or higher generally considered to be strongly positive. The samples here diverge from those typically used in social research in that they were not collected randomly; instead I sampled the entire population of particular encampments. Interested readers 
can obtain more information on statistical tests of this kind from on-line tutorials, such as those posted at https://libguides.library.kent.edu/SPSS/PearsonCorr.

17. In prior decades, wool and pelts were important sources of income, and lamb and mutton were important sources of meat - so much so that castrated males are known as sha bzan, literally "meat eating", or, essentially, meat on the hoof, in the regions I studied. Elsewhere there were sha ra, "meat goats", animals destined for slaughter (Holler 2002, p. 2015). Sulek (2011, p. 18) argues that cash from sales of caterpillar fungus and the availability of market-bought mutton meant that pastoralists in Machen County no longer had to worry about owning diversified multi-species herds (compare Næss 2004, pp. 84-86 on the value of such herds for subsistence pastoralists in western Tibet).

18. In prior decades, epidemic disease may have been a greater threat, and one Jigdril pastoralist with whom I spoke described the "old world" (jig rten rnying pa) as a time without medicine, when many animals died. Veterinary services were first provided to these regions in the late 1950s. Predators, wolves in particular, continue to pose a threat to animals, increased in the modern period by proscriptions on gun ownership. Tsewang Namgail et al. (2007) have quantified losses from predators for Ladakhi agropastoralists.

19. I conducted household interviews in southeastern Dzachuka and in encampments in Matod located near the road to Jyekundo. Even though at some distance from the worst affected areas, these townships suffered major losses of animals during the 1995-1996 blizzards.

20. County wide, 280000 animals are reported as having died following the 1996 blizzards. Dzachuka pastoralists suffered lower animal mortality during 1998. While that year's snows were repeated and heavy, there was no freezing, and animals were able to reach forage.

21. Fijn (2011, pp. 43-45) made a similar point about seter in Mongolia, which become akin to sacred animals in ensuring the health and safety of the herd, the herding family, and the surrounding landscape and also recall ideas among Mongolian and Siberian hunting peoples about "chief" animals and "masters of the forest".

22. Wishful thinking about relationships with animals extending beyond death may be familiar to readers of this essay who have heard the poem of the Rainbow Bridge, which portrays a heavenly reunion with deceased pets - a poem that is gaining increasing popularity around the world.

23. Da Col has provided the most thoroughgoing analysis of the "field of fortune" in Tibetan societies (da Col 2012), the ontologies of luck, contingency, and fortune, how they are conceptualized, and the technologies (or economies) used to achieve and secure vitality and prosperity.

\section{ABSTRACTS}

This paper discusses the multifaceted relationships between Tibetan pastoralists in Sichuan and Qinghai Provinces and the domestic animals on which they depend. It shows how pastoralists organize their lives around their animals and balance their household's needs and work capacities against their animals' needs for care in order to achieve a productive, economic symbiosis. The paper discusses the constraints on herd management imposed by government policies concerning land use, the severe weather events that have claimed many animals' lives, and the strategies pastoralists have used to rebuild their herds after such setbacks. Finally, the paper discusses practices of dedicating certain animals as tsetar, exempt from sale and slaughter, in order to offset household members' sins and alleviate misfortunes of various kinds. This 
practice reflects the mix of attitudes - pragmatic, symbolic, and emotional - that these eastern Tibetan pastoralists have about the animals amongst whom they live, their commitments to Buddhist religious principles, and ideas about the ways in which domestic animals can enhance both spiritual capital and social reputation.

Cet article discute des relations à facettes multiples entre les pasteurs nomades tibétains des provinces du Sichuan et Qinghai et leurs animaux domestiques. Il montre la façon dont ces pasteurs nomades organisent leur vie autour de leurs animaux et trouvent un équilibre, d'une part, entre les besoins de leur maisonnée et leurs capacités de travail et, d'autre part, les besoins de leurs animaux en matière de soins, dans le but d'arriver à une symbiose économiquement productive. Cet article discute aussi les contraintes sur la gestion des troupeaux entrainées par les politiques gouvernementales concernant l'utilisation des terres, les événements météorologiques sévères qui tuent de nombreux animaux, ainsi que des stratégies utilisées par les pasteurs nomades pour reconstruire les troupeaux après de tels événements. Finalement, l'article présente la pratique de « libérer » certains animaux en tant que tsetar, c'est à dire de les rendre interdits de vente et d'abattage dans le but de compenser les péchés commis par les membres de la maisonnée et d'atténuer les malchances diverses. Cette pratique reflète un mélange d'attitudes (pragmatique, symbolique et émotionnelle) dont font preuve les pasteurs nomades de l'est du Tibet à l'égard de leurs animaux au milieu desquels ils vivent, souligne leur dévouement aux principes bouddhiques ainsi que leurs idées quant à la façon dont les animaux domestiques peuvent améliorer leur capital spirituel et leur réputation.

\section{INDEX}

Mots-clés: Tibet, Sichuan, Qinghai, Chine, nomadisme, économie, domestique, catastrophe naturelle, bouddhisme

Keywords: Tibet, Sichuan, Qinghai, China, nomadism, pastoralism, economy, household, natural disaster, Buddhism

\section{AUTHOR}

\section{NANCY E. LEVINE}

Nancy E. Levine is Professor in the Department of Anthropology at the University of California, Los Angeles. She has carried out long-term research in Tibetan-speaking farming communities of northwestern Nepal and among eastern Tibetan pastoralists living in today's Gansu, Qinghai and Sichuan Provinces. That research has focused on the socio-cultural dimensions of kinship and gender, the management of household economies, the sources and consequences of food insecurity and social inequalities, the impacts of government-instituted social and economic policies, together with processes of modernization, urbanization, and sedentarization, on family relationships, health, and well-being.

nelevine@anthro.ucla.edu 